\title{
Pimenta Leaf Oil
}

National Cancer Institute

\section{Source}

National Cancer Institute. Pimenta Leaf Oil. NCI Thesaurus. Code C72207.

The essential oil extracted from the leaves of Pimenta dioica. Pimenta leaf oil is used to treat tooth and gum pain. 